\title{
Common bean genotypes for agronomic and market-related traits in VCU trials
}

\author{
Alisson Fernando Chiorato*, Sérgio Augusto Morais Carbonell, Fátima Bosetti, Graziele Ramos Sasseron, Rodrigo Lorencetti \\ Tunes Lopes, Cleber Vinícius Giaretta Azevedo
}

Agronomic Institute (IAC), Av. Barão de Itapura, C.P. 28 13012-970 - Campinas, SP - Brazil.

*Corresponding author < afchiorato@iac.sp.gov.br>

Edited by: Martin Boer

Received June 05, 2013

Accepted July 24, 2014

\begin{abstract}
Value for Cultivation and Use (VCU) trials are undertaken when evaluating improved common bean (Phaseolus vulgaris L.) lines, and knowledge of agronomic and market-related traits and disease reaction is instrumental in making cultivar recommendations. This study evaluates the yield, cooking time, grain color and reaction to anthracnose (Colletotrichum lindemuthianum), Fusarium wilt (Fusarium oxysporum f. sp. phaseoli) and Curtobacterium wilt (Curtobacterium flaccumfaciens pv. flaccumfaciens) of 25 common bean genotypes derived from the main common bean breeding programs in Brazil. Seventeen VCU trials were carried out in the rainy season, dry season and winter season from 2009 to 2011 in the state of São Paulo. Analyses of grain color and cooking time were initiated 60 days after harvest, and disease reaction analyses were performed in the laboratory under controlled conditions. In terms of yield, no genotype superior to the controls was observed for any of the seasons under consideration. Grains from the dry season exhibited better color, while the rainy season led to the shortest cooking times. The following genotypes BRS Esteio, BRS Esplendor and IAC Imperador were resistant to anthracnose, Fusarium wilt and Curtobacterium wilt and, in general, genotypes with lighter-colored grains were more susceptible to anthracnose and Fusarium wilt.
\end{abstract}

Keywords: Phaseolus vulgaris, Fusarium wilt, Curtobacterium wilt, anthracnose, selection

\section{Introduction}

Value for Cultivation and Use (VCU) trials in the common bean Genetic Breeding Program of the Agronomic Institute (IAC) were undertaken in the state of São Paulo, Brazil, in an evaluation of improved common bean lines in keeping with standards established by the Brazilian Ministry of Agriculture, Livestock and Food (Ministério da Agricultura, Pecuária e Abastecimento MAPA).

Consumers of common bean take nutritional, industrial and commercial traits into consideration, and the most important traits are grain size, seed coat color, mechanical damage and cooking time (Peña-Valdivia et al., 2011). Cooking time should be considered by common bean breeding programs since cooking is required for consumption of these grains. It also contributes to characterization of the sensory properties of color, taste and texture, which consumers consider appealing (Wang et al., 2003; Shimelis and Rakshit, 2005).

Together with grain traits, it is just as important to identify common bean genotypes that exhibit genetic resistance or tolerance to the main diseases that can afflict the crop. Anthracnose (Colletotrichum lindemuthianum) is considered to be one of the main diseases that attacks the part of the plant that is above ground. This pathogen exhibits high pathogenic variability, and, in the state of São Paulo, nine races causing significant damage to commercial crops have already been identified (Carbonell et al., 1999). Fusarium wilt, caused by the fungus Fusarium oxysporum f. sp. phaseoli is among the most important soil diseases that affect common bean. Seven physiological races of Fusarium oxysporum distributed in different regions of the world have been described, with indications that, in Brazil, there is a predominance of race 2 (Alves-Santos et al., 2002a). As regards bacterial diseases, Curtobacterium wilt of the common bean (Curtobacterium flaccumfaciens pv. flaccumfaciens) is a relatively new disease, that is found throughout the main producing regions of the world (Hsieh et al., 2004) and is becoming increasingly significant in Brazil.

This study aimed to evaluate the yield of $25 \mathrm{com}$ mon bean genotypes sown in 17 environments in the state of São Paulo, to determine the cooking time and grain color of the genotypes in different crop seasons, and to evaluate the reaction of the genotypes to physiological races 31, 65 and 81 of Colletotrichum lindemuthianum, to the mixture of races I and II of Fusarium oxysporum, and to an isolate of Curtobacterium flaccumfaciens.

\section{Materials and Methods}

A total of 25 common bean genotypes were evaluated, with 13 genotypes from the Agronomic Institute (IAC), five from the Brazilian Agricultural Research Corporation - EMBRAPA, two from the Agricultural Research and Rural Extension of Santa Catarina - EPAGRI, two from the Federal University of Lavras - UFLA and three from the Paraná Agronomic Institute - IAPAR (Table 1). The 2009/2010/2011 VCU trials consisted of 17 experiments conducted in the state of São Paulo in the following locations, crop seasons, and years: Capão Bonito $\left(24^{\circ} 0^{\prime} \mathrm{S} ; 48^{\circ} 20^{\prime} \mathrm{W}\right)$ and Mococa $\left(21^{\circ} 28^{\prime} \mathrm{S} ; 47^{\circ} 0^{\prime} \mathrm{W}\right)$ in

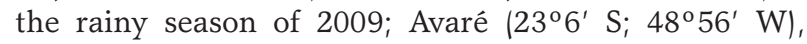
Mococa and Tatuí $\left(23^{\circ} 21^{\prime} \mathrm{S}\right.$; $\left.47^{\circ} 51^{\prime} \mathrm{W}\right)$ in the dry season of 2010; Andradina (20 $\left.53^{\prime} \mathrm{S} ; 51^{\circ} 23^{\prime} \mathrm{W}\right)$, Espírito Santo do Pinhal $\left(22^{\circ} 10^{\prime} \mathrm{S} ; 46^{\circ} 45^{\prime} \mathrm{W}\right)$ and Votuporanga $\left(20^{\circ} 25^{\prime} \mathrm{S} ; 4^{\circ} 58^{\prime} \mathrm{W}\right)$ in the winter season of 2010; Av- 
Table 1 - Comparison of mean values for grain yield of 25 common bean genotypes in the 2009 and 2010 rainy crop seasons, 2010 and 2011 dry crop seasons and the 2010 and 2011 winter crop seasons in environments in the state of São Paulo, and for reaction to the pathogens of anthracnose (Colletotrichum lindemuthianum), Fusarium wilt (Fusarium oxysporum) and Curtobacterium wilt (Curtobacterium flaccumfaciens).

\begin{tabular}{|c|c|c|c|c|c|c|c|c|c|}
\hline \multirow{2}{*}{$\begin{array}{l}\text { Common Bean Cultivars } \\
\text { and Lines }\end{array}$} & \multicolumn{3}{|c|}{ Yield in Crop Seasons ${ }^{1}$} & \multirow{2}{*}{$\begin{array}{l}\text { Joint } \\
\text { analysis }\end{array}$} & \multicolumn{3}{|c|}{$\begin{array}{l}\text { Reaction to Physiological } \\
\text { Races of } \\
\text { C. lindemuthianum² }\end{array}$} & \multirow{2}{*}{$\begin{array}{c}\begin{array}{c}\text { Reaction to } \\
\text { Fusarium } \\
\text { oxysporum }^{3}\end{array} \\
\begin{array}{c}\text { Mixture of } \\
\text { Races I and II }\end{array}\end{array}$} & \multirow{2}{*}{$\begin{array}{c}\text { Reaction to } \\
\text { Curtobacterium } \\
\text { flaccumfaciens }\end{array}$} \\
\hline & Rainy & Dry & Winter & & Race31 & Race65 & Race 81 & & \\
\hline & & $-\mathrm{kg}$ & $a^{-1}-$ & & & & & & \\
\hline IAC Alvorada (IAC Carioca) & 1929 & 2172 & 2471 & 2191 & $\mathbf{S}$ & S & $\mathbf{S}$ & S & $\mathbf{R}$ \\
\hline BRS Pérola (Embrapa Carioca) & 2149 & 2374 & 2638 & 2387 & S & $\mathbf{S}$ & S & MR & S \\
\hline IAC Diplomata (IAC Preto) & 2042 & 2141 & 2228 & 2137 & $\mathbf{R}$ & $\mathbf{R}$ & $\mathbf{R}$ & MR & $\mathbf{S}$ \\
\hline IAC Una (IAC Preto) & 2277 & 2344 & 2369 & 2330 & $\mathbf{R}$ & $\mathbf{R}$ & $\mathbf{R}$ & MR & $\mathbf{S}$ \\
\hline Gen C2-1-6-1 (IAC Carioca) & 2141 & 2611 & 2421 & 2391 & $\mathbf{S}$ & $\mathbf{S}$ & s & $\mathbf{S}$ & MR \\
\hline Gen C2-1-6-1-1 (IAC Carioca) & 2506 & 2353 & 2631 & 2497 & S & $S$ & S & $S$ & $\mathbf{S}$ \\
\hline Gen C2-3-1-1-2 (IAC Carioca) & 2183 & 2448 & 2527 & 2386 & s & s & s & S & s \\
\hline Gen C4-5-4-1-2 (IAC Carioca) & 1529 & 1830 & 2308 & 1889 & S & S & $\mathbf{s}$ & $\mathbf{S}$ & $\mathbf{R}$ \\
\hline Gen C4-8-1-1 (IAC Carioca) & 1968 & 2048 & 2549 & 2188 & $\mathbf{R}$ & $\mathbf{R}$ & $\mathbf{R}$ & s & $\mathbf{R}$ \\
\hline CHC 97-29 (Epagri Carioca) & 2618 & 2147 & 2456 & 2407 & $\mathbf{S}$ & $\mathbf{S}$ & S & $\mathbf{R}$ & MR \\
\hline CHP 98-59 (Epagri Preto) & 2041 & 2370 & 2542 & 2318 & $\mathbf{S}$ & $\mathbf{S}$ & $\mathbf{S}$ & $\mathbf{S}$ & $\mathbf{S}$ \\
\hline BRS Esteio (Embrapa Preto) & 2451 & 2578 & 2619 & 2549 & $\mathbf{R}$ & $\mathbf{R}$ & $\mathbf{R}$ & $\mathbf{R}$ & MR \\
\hline BRS Cometa (Embrapa Carioca) & 1961 & 2078 & 2374 & 2138 & $\mathbf{R}$ & $\mathbf{R}$ & $\mathbf{s}$ & $\mathbf{S}$ & $\mathbf{S}$ \\
\hline IPR Eldorado (IAPAR Carioca) & 2140 & 2191 & 2411 & 2247 & S & S & S & $\mathbf{R}$ & s \\
\hline BRS Esplendor (Embrapa Preto) & 2242 & 2498 & 2611 & 2450 & $\mathbf{R}$ & $\mathbf{R}$ & $\mathbf{R}$ & $\mathbf{R}$ & $\mathbf{R}$ \\
\hline BRS Estilo (Embrapa Carioca) & 2225 & 2291 & 2458 & 2325 & $\mathbf{R}$ & $\mathbf{R}$ & $\mathbf{R}$ & S & MR \\
\hline LP 0403 (IAPAR Carioca) & 2385 & 2636 & 2523 & 2515 & $\mathbf{R}$ & $\mathbf{R}$ & s & $\mathbf{R}$ & MR \\
\hline L P 0577(IAPAR Carioca) & 2017 & 2428 & 2452 & 2299 & S & S & s & $\mathbf{R}$ & $\mathbf{R}$ \\
\hline MAll-22 (UFLA Carioca) & 1921 & 2277 & 2279 & 2159 & s & $\mathbf{R}$ & s & MR & S \\
\hline IAC Imperador (IAC Carioca) & 2355 & 2480 & 2521 & 2452 & $\mathbf{R}$ & $\mathbf{R}$ & $\mathbf{R}$ & $\mathbf{R}$ & $\mathbf{R}$ \\
\hline Gen P5-4-4-1 (IAC Carioca) & 1735 & 2122 & 2557 & 2138 & $\mathbf{R}$ & $\mathbf{R}$ & $\mathbf{R}$ & S & s \\
\hline Gen Pr11-3-5-1 (IAC Carioca) & 2178 & 2358 & 2525 & 2354 & $\mathbf{R}$ & $\mathbf{R}$ & $\mathbf{R}$ & $\mathbf{R}$ & $\mathbf{S}$ \\
\hline Gen Pr11-6-4-1-2 (IAC Preto) & 1689 & 1938 & 2488 & 2038 & $\mathbf{R}$ & $\mathbf{R}$ & $\mathbf{R}$ & s & MR \\
\hline Gen Pr14-2-3-2 (IAC Preto) & 1914 & 2258 & 2535 & 2236 & $\mathbf{R}$ & $\mathbf{R}$ & $\mathbf{R}$ & MR & S \\
\hline RP-2 (UFLA Carioca) & 2396 & 2186 & 2404 & 2329 & $\mathbf{s}$ & $\mathbf{R}$ & s & $\mathrm{s}$ & s \\
\hline${ }^{4}$ Mean & $2111 \mathrm{C}$ & 2268 B & 2476 A & 2294 & --- & --- & --- & -- & $-\cdots$ \\
\hline CV (\%) & 21.56 & 18.96 & 16.74 & 17.19 & --- & -- & --- & -- & -- \\
\hline DMS kg ha-1 & 632 & 468 & 355 & 235 & --- & -- & --- & --- & --- \\
\hline
\end{tabular}

${ }^{1}$ Values in bold print correspond to the best standard cultivar of comparison by the Dunett test (5\%) for the corresponding commercial group (IAC Alvorada and BRS Pérola for the carioca group and IAC Una and IAC Diplomata for the black group); ${ }^{2}$ Resistance/susceptibility reaction to the pathogen evaluated (R - Resistant; $\mathrm{S}$ - Susceptible); ${ }^{3}$ Resistance/susceptibility reaction to the pathogen evaluated (R - Resistant; MR - Moderately Resistant; $\mathrm{S}-\mathrm{Susceptible);}{ }^{4}$ Mean values followed by the same letter do not differ (Skott-Knott test, $p<0.05$ ).

aré, Capão Bonito and Mococa in the rainy season of 2010; Avaré, Capão Bonito and Mococa in the dry season of 2011; and Colina $\left(20^{\circ} 42^{\prime}\right.$ S; $\left.48^{\circ} 32^{\prime} \mathrm{W}\right)$, Ribeirão Preto $\left(21^{\circ} 10^{\prime} S ; 47^{\circ} 49^{\prime} \mathrm{W}\right)$ and Votuporanga in the winter season of 2011. The experiments sown in the winter season received supplemental irrigation.

A randomized block experimental design was used according to the MAPA standards for VCU trials, with three replications. Plots consisted of four $4 \mathrm{~m}$ length rows, spaced at $0.50 \mathrm{~m}$, with 10 to 12 viable plants per meter, the useful area of the plot being the two center rows.

Evaluations pertaining to cooking time (CT) and grain color were carried out 60 days after harvest as described by Perina et al. (2014). For this purpose, the grains were classified in a size 13 sieve (13/64") with oblong holes. This classification aimed to standardize grain size and make sample exhibit grains with a pattern as required by the packaging industry. Grains visually perceived as grains damaged by insects or mechanically damaged were removed. Mean cooking time (CT) was determined through the use of three replications with 25 grains per replication, obtained from a $30 \mathrm{~g}$ sample for each genotype. These uniform grains were soaked in distilled water for $16 \mathrm{~h}$ at room temperature. After this period, the 25 grains were individually placed in the orifices at the base of the Mattson cooker, and the device was placed in a beaker containing 1000 $\mathrm{mL}$ of boiling distilled water. Cooking time, measured in the Mattson cooker, was interrupted on the fall of the thirteenth rod out of a total of 25 (Proctor and Watts, 1987). 
Evaluation of seed coat color was performed with a manual colorimeter, model CR-410. Quantification of the $\mathrm{L}^{*}$ (luminosity) parameter followed the CIE 1976 $\left(\mathrm{L}^{*} \mathrm{a}^{*} \mathrm{~b}^{*}\right)$ color scale system, in which the parameter $\mathrm{L}^{*}$ represents the luminosity scale from 0 to 100 (Ribeiro et al., 2008). The standard illuminant D65 was used (corresponding to daylight, including ultraviolet light) and $2^{\circ}$ standard observer. This value was presented in the form of a Unit of Measurement (u.m.) of the parameter. Ribeiro et al. (2008) affirm that carioca (beige with brown stripes) genotypes with $\mathrm{L}^{*}$ greater than 55 and black genotypes with $\mathrm{L}^{*}$ less than 22 have greater market value; however, they state that these values are empirical and subjective.

The data obtained were subjected to individual analyses of variance for each environment so as to evaluate experimental precision, rejecting experiments that had coefficients of variation above $25 \%$ for grain yield. The data were then subjected to joint analyses of variance of the group of environments for each crop season and a joint analysis of the three crop seasons. To obtain yield and cooking time, the mean values of the genotypes were compared to the following controls: IAC Alvorada and BRS Pérola (carioca commercial group) and IAC Diplomata and IAC Una (black commercial group) by the Dunnett test $(p<0.05)$, and the differences of mean values between crop seasons were analyzed by the Scott-Knott test $(p<0.05)$. For grain color, the mean values of the $\mathrm{L}^{*}$ parameter of the genotypes were compared using the Scott-Knott test $(p<0.05)$ by means of the GENES program (Cruz, 2013).

For inoculation of the pathogens that cause anthracnose, Fusarium wilt and Curtobacterium wilt, isolates that came from the Plant Health Center of the Agronomic Institute (IAC) were used. For inoculation with anthracnose (C. lindemuthianum), six seedlings for each genotype, with two replications, were used, sown in a box with vermiculite. Isolates of physiological races 31 , 65 and 81 of $C$. lindemuthianum were sprayed on the genotypes separately by race with a conidium suspension at a concentration of $10^{6}$ conidia $\mathrm{mL}^{-1}$, The seedlings were then stored in a room in temperature conditions of around $23{ }^{\circ} \mathrm{C}, 90 \%$ humidity and controlled luminosity with a 12-hour photoperiod. Evaluation of symptoms in the seedlings with regard to infection response was made 7 to 10 days after inoculation, using a scale 1-9, 1 being resistant and without symptoms to 9 being susceptible and dead.

For inoculation of Fusarium oxysporum f. sp. phaseoli, the experimental design consisted of three pots for each genotype containing two inoculated seedlings per pot. For spore transfer to the pots, the plants were immersed in a suspension of spores at a concentration of $10^{6}$ conidia $\mathrm{mL}^{-1}$ for $10 \mathrm{~min}$ and then planted in pots containing a sterilized mixture of soil and sand. Evaluation of symptoms was made 30 days after inoculation, adopting a scoring scale from 1 to 3 for plants to be classified as resistant (R), 4 to 5 as moderately resistant (MR) and 6 and above as susceptible (S) plants. For inoculation of the pathogen, a mixture of isolates of races I (American) and II (Brazilian) was used, as already described by Alves-Santos et al. (2002b).

Inoculation of Curtobacterium flaccumfaciens pv. flaccumfaciens was performed through punctures in the stem between the cotyledonary leaves with an entomological needle previously moistened in bacterial colonies. The experimental design consisted of three pots for each genotype, each pot containing two inoculated plants. Disease symptoms were evaluated $30 \mathrm{~d}$ after inoculation, attributing scores which ranged from 0 to 9 , according to Souza et al. (2006). As per this scale, the genotypes that obtained an average score lower than 2.33 were considered resistant (R), genotypes with an average score from 2.34 to 4.0 were considered moderately resistant (MR), and above this score, genotypes were considered susceptible (S).

\section{Results and Discussion}

None of the crop seasons exhibited genotypes superior to the corresponding standards (Dunnett test, $p$ $<0.05$ ) (Table 1). In the combination of the three crop seasons of 2009/2010/2011, although no genotype with a yield higher $(p<0.05)$ than that of the best control was identified, it is noted that the genotypes had a performance similar to that of the respective standard cultivars and are considered sufficient for recommending new common bean cultivars for the agricultural sector.

The rainy season produced the lowest mean yield (2111 $\mathrm{kg} \mathrm{ha}^{-1}$ ) when compared to the other crop seasons, i.e., the dry $\left(2268 \mathrm{~kg} \mathrm{ha}^{-1}\right)$ and winter (2476 kg ha-1) seasons. The lower yield observed for the rainy season in this study may be explained by the occurrence of a strong infestation of silver leaf whitefly (Bemisia tabacci), where the experiment in Mococa showed a mean yield of $940 \mathrm{~kg} \mathrm{ha}^{-1}$ and the Capão Bonito experiment did not go beyond $1500 \mathrm{~kg} \mathrm{ha}^{-1}$.

For the dry season, the genotypes that stood out were the BRS Esteio cultivar, with a black seed coat and a mean yield of $2578 \mathrm{~kg} \mathrm{ha}^{-1}$, the carioca seed coat line Gen C2-1-6-1, with a mean yield of $2611 \mathrm{~kg} \mathrm{ha}^{-1}$, and LP 0403, with a mean yield of $2636 \mathrm{~kg} \mathrm{ha}^{-1}$.

The winter season was that which showed the greatest yield values, with a mean of $2476 \mathrm{~kg} \mathrm{ha}^{-1}$. It also showed the least yield difference among the genotypes. The genotypes that stood out in the winter season were the standard control cultivar of the carioca group, BRS Pérola, and the Gen C2-1-6-1-1, BRS Esteio and BRS Esplendor genotypes of the black group.

When data from joint analysis work are considered, the performance of the LP 0403, Gen C2-1-6-1-1 lines and the IAC Imperador cultivar changes. The IAC Imperador cultivar, which was not mentioned as standing out among the crop seasons, was in $4^{\text {th }}$ place when considering only the joint analysis mean yield in reference to the 17 experiments performed. It exhibited 
a mean yield of $2452 \mathrm{~kg} \mathrm{ha}^{-1}$. This result arises from stability of production because, to obtain fourth place, small changes had to occur in the yield values during the crop periods from 2009 to 2011. A similar result was obtained for the BRS Esplendor cultivar, with a mean yield of $2450 \mathrm{~kg} \mathrm{ha}^{-1}$ and in $5^{\text {th }}$ place in joint analysis. These cultivars stand out from the others because the identification of more stable and adapted cultivars, in addition to more productive ones, has been an alternative widely used by common bean breeding programs in various regions in Brazil (Carbonell et al., 2004; Torga et al., 2013) that allow for more reliable recommendations .

The IAC Imperador and BRS Esplendor cultivars stood out by showing resistance to the three physiological races of Colletotrichum lindemuthianum, which cause anthracnose, to the mixture of the two races of Fusarium oxysporum (race 1 and race 2), which causes Fusarium wilt, and to the isolate of Curtobacterium flaccumfaciens, which causes Curtobacterium wilt (Table 1).

Race 81 of Colletotrichum lindemuthianum was identified by the common bean genetic breeding program of IAC as the race of pathogen of greatest importance because of its aggressiveness and because it is the most frequently recurring race in the state of São Paulo, and other Brazilian states. When the genotypes of Table 1 are compared, most were susceptible to race 81 and resistant to races 31 and 65 . This result may be explained by the fact that selection processes in the past were directed to obtaining genotypes resistant to race 65 of anthracnose, which was described as the most widespread in Brazil in the 1990s (Carbonell et al., 1999). The cultivars IAC Diplomata, IAC Una, BRS Estilo, BRS Esplendor, BRS Esteio, and IAC Imperador and the lines Gen C4-81-1, Gen P5-4-4-1, Gen Pr11-3-5-1, Gen Pr 11-6-4-1-2 and Gen Pr14-2-3-2 stand out for resistance to anthracnose as they are resistant to all three races of the pathogen.

The lack of genotypes superior to the standard controls of the carioca group in terms of yield is noteworthy, mainly because the control for comparison of the carioca seed coat was the BRS Pérola cultivar, introduced in 1998 by EMBRAPA. The absence of genetic gain is normally indicated as a consequence of the narrowing of the genetic base and the use of related parents in breeding programs, which restricts the variability available for carrying out selection (McCouch, 2005). Thus, the inability to obtain genotypes superior to the controls for grain yield could be explained by pointing to restrictions in the genetic base of the breeding programs in Brazil. But, in practice, this does not occur, as identified by Perseguini et al. (2011), who analyzed the genetic base of 60 genotypes of carioca seed coat, including the main cultivars developed in Brazil, and proved that the genetic base of the common bean breeding programs in Brazil is not narrow.

An explanation for this absence of yield superiority of the new cultivars in relation to the controls could be the fact that inclusion of selection for agronomic and technological traits of the grains required by the con- sumer market reduces genetic progress in common bean yield. Considering the genetic breeding program carried out by the Agronomic Institute (IAC) Chiorato et al. (2010) studied the genetic progress of the program from 1989 to 2007 and found that as of 1998 there were decreases in the genetic progress of the program due to selections aimed at increasing the size of the grains, shorter cooking time and resistance to darkening. The gains in technological quality of grains in this period are seen through a reduction in cooking time (Table 2) and lighter-colored grains (Table 3) of the current lines when compared to the control, BRS Pérola, introduced in 1998. Another result that may also be related to the lack of superiority of some genotypes in relation to the controls would be the experimental precision of the trials, which did not allow for small differences from the standards to be detected.

Evaluations of cooking time (CT) carried out for the genotypes (Table 2) in the rainy season indicated that the lines Gen C2-1-6-1, Gen C2-3-1-1-2 and LP04-03 lines and the BRS-Cometa cultivar were superior in relation to the control, IAC Alvorada, in shorter cooking time. With regard to the dry season, the Gen C2-1-6-1, Gen P5-4-4-1 and IAC Imperador lines showed CT lower than that of the control, BRS Pérola. In the winter season, the Gen P5-4-4-1line stood out, with CT lower than that of the controls. Among the genotypes evaluated, the CT ranged from $26^{\prime} 51^{\prime \prime}$ to $32^{\prime} 10^{\prime \prime}$ for the combination of the three crop seasons. This variation is due to the genetic differences present in the genotypes, environmental influence and genotype by environment interaction (Dalla Corte et al., 2003; Perina et al., 2014). The results for CT indicated that the Gen C2-1-6-1, Gen C2-3-1-1-2, BRS Cometa, LP 0403, IAC Imperador, and Gen P5-4-4-1 genotypes stood out in relation to the standard control for the carioca group, and the Gen Pr11-6-4-1-2 line stood out among the genotypes in the black group.

The CT mean values reported for crop seasons showed differences (Table 2). The CT values for the rainy season were lower than those of the dry and winter seasons, as expected, since the rainy season is considered most favorable for differentiating genotypes that are superior in cooking time (Perina et al., 2014). Nevertheless, in the literature, lower values are found for cooking time in the dry season (Perina et al., 2014), indicating that cooking time may also be related to the quality of the grain at the time of harvest.

For colorimetry analyses (Table 3), differences $(p<0.05)$ were found for the mean values of the crop seasons, and the aim was to find genotypes with light colored grain, the carioca grain being known as "milk type", and non-purplish grains for the black seed coat. Consumer acceptance of the bean grain takes the visual aspect into consideration since light-colored grains for the carioca seed coat are associated with being recently harvested and rapidly cooked and, for black seed coat grains, less of a light color is mainly associated with a thick broth after cooking. A higher value (54.39) for $\mathrm{L}^{*}$ 
Table 2 - Comparison of mean values of cooking time (CT) of grains of 25 common bean genotypes grown in the 2009 and 2010 rainy sowing seasons, 2010 and 2011 dry sowing seasons and the 2010 and 2011 winter sowing seasons in environments in the state of São Paulo.

\begin{tabular}{|c|c|c|c|c|}
\hline \multirow{2}{*}{ Common Bean Cultivars/Lines } & \multicolumn{4}{|c|}{$\mathrm{CT}(\mathrm{min})^{1}$} \\
\hline & Rainy & Dry & Winter & Joint Analysis \\
\hline Gen C2-1-6-1 (IAC Carioca) & $22.58^{*}$ & $25.27^{*}$ & 33.39 & $27.08^{*}$ \\
\hline GenC2-1-6-1-1 (IAC Carioca) & 25.46 & 32.15 & 31.17 & 29.59 \\
\hline GenC2-3-1-1-2 (IAC Carioca) & $23.11^{*}$ & 26.35 & 34.57 & $28.01^{*}$ \\
\hline GenC4-5-4-1-2 (IAC Carioca) & 26.51 & 28.18 & 40.35 & 32.08 \\
\hline GenC4-8-1-1 (IAC Carioca) & 26.39 & 27.37 & 32.58 & 29.18 \\
\hline CHC 97-29 (Epagri Carioca) & 27.21 & 33.15 & 32.25 & 31.27 \\
\hline CHP 98-59 (Epagri Preto) & 28.18 & 29.15 & 34.34 & 30.56 \\
\hline BRS Esteio (Embrapa Preto) & 24.01 & 31.36 & 31.51 & 29.36 \\
\hline BRS Cometa (Embrapa Carioca) & $24.12^{*}$ & 26.21 & 35.19 & $28.51^{*}$ \\
\hline IPR Eldorado (IAPAR Carioca) & 25.31 & 27.52 & 37.09 & 30.37 \\
\hline BRS Esplendor (Embrapa Preto) & 29.00 & 31.24 & 36.05 & 32.10 \\
\hline BRS Estilo (Embrapa Carioca) & 27.09 & 30.36 & 36.60 & 31.35 \\
\hline LP 0403 (IAPAR Carioca) & $23.28^{*}$ & 30.24 & 31.27 & $28.26^{*}$ \\
\hline LP 0577 (IAPAR Carioca) & 27.04 & 28.09 & 36.21 & 30.45 \\
\hline MAll-22 (UFLA Carioca & 26.37 & 27.10 & 39.02 & 31.23 \\
\hline IAC Imperador (IAC Carioca) & 25.49 & $24.58^{*}$ & 34.01 & $28.03^{*}$ \\
\hline GenP5-4-4-1 (IAC Carioca) & 26.12 & $25.17^{\star}$ & $28.23^{*}$ & $26.51^{*}$ \\
\hline GenPr11-3-5-1 (IAC Carioca) & 28.20 & 26.02 & 32.04 & 29.15 \\
\hline GenPr11-6-4-1-2 (IAC Preto) & 25.18 & 29.12 & 29.01 & $28.17^{*}$ \\
\hline GenPr14-2-3-2 (IAC Preto) & 27.39 & 30.02 & 33.39 & 30.27 \\
\hline RP-2 (UFLA Carioca) & 29.12 & 27.56 & 37.22 & 31.30 \\
\hline IAC Alvorada(IAC Carioca) & 27.37 & 30.36 & 32.14 & 30.36 \\
\hline BRS Pérola (Embrapa Carioca) & 28.11 & 28.16 & 36.08 & 30.78 \\
\hline IAC Diplomata (IAC Preto) & 24.11 & 27.21 & 33.15 & 28.16 \\
\hline IAC Una (IAC Preto) & 24.17 & 29.33 & 32.45 & 28.65 \\
\hline Mean $^{2}$ & $26.15 \mathrm{~A}$ & $29.30 \mathrm{~B}$ & $34.38 \mathrm{C}$ & 29.49 \\
\hline CV (\%) & 3.20 & 3.99 & 4.01 & 5.48 \\
\hline DMS kg ha-1 & 2.30 & 2.75 & 2.23 & 1.32 \\
\hline
\end{tabular}

VValues in bold print correspond to the best standard cultivar of comparison by the Dunnett test (5\%) for the corresponding commercial group (IAC Alvorada and BRS Pérola for the carioca group and IAC Una and IAC Diplomata for the black group); ${ }^{2}$ Mean values followed by the same letter do not differ (Skott-Knott test, $p<$ 0.05); * Significant (Dunnett test, $p<0.05$ ).

was obtained in the dry season (Table 3), in comparison to the winter (51.72) and rainy (51.06) seasons, which did not differ $(p<0.05)$ between themselves, thus showing that for the dry season, the seed coats of recently harvested grains were lighter-colored.

For the black seed coat grains, an $\mathrm{L}^{*}$ value less than 22 was not observed (Table 3). According to Ribeiro et al. (2008), an $\mathrm{L}^{*}$ value less than 22 has greater commercial value. The dry (23.81) and rainy (23.86) seasons, which did not differ between themselves, showed more satisfactory results than the winter season (24.15) (Table 3).

In the rainy season, the genotypes with carioca seed coat with greater $L^{*}$ value, were higher than 53, which have greater commercial value, as suggested by Ribeiro et al. (2008), were Gen C2-3-1-1-2 (53.61) and Gen C2-1-6-1 (53.06). For the dry season, the genotypes with a lighter-colored carioca seed coat were Gen C2-1-61 (56.76), Gen C2-1-6-1-1 (56.71), Gen C4-5-4-1-2 (56.57), Gen C2-3-1-1-2 (56.36) and IAC Alvorada (55.77). It is noteworthy that in this season, only five genotypes did not show values greater than 53 . In the winter season, the genotypes Gen C4-5-4-1-2 (54.46), Gen C2-1-6-1-1 (54.28) and Gen C2-1-6-1 (54.14) had a carioca seed coat that stood out. The values found for the combination of the three seasons display the genotypes Gen C2-1-6-1 (54.65), Gen C2-1-6-1-1 (54.56), Gen C2-3-1-1-2 (54.15) and Gen C4-5-4-1-2 (53.67) as grains with a lighter-colored carioca seed coat (Table 3).

The genotypes with lighter-colored grains, such as the Gen C2-1-6-1, Gen C2-1-6-1-1, Gen C2-3-1-1-2, Gen C4-5-4-1-2 lines and the IAC Alvorada cultivar, were generally susceptible to anthracnose and to Fusarium wilt. Darkening in beans may be related to the presence of polyphenolic compounds (Beninger et al., 2005), and these compounds are directly connected with plant defense against pathogens (Islam et al., 2003). Selection directed to obtaining lighter-colored grains causes the phenolic compounds to be reduced in the plant, for these compounds are active in oxidation which accelerates grain darkening. With regard to yield, there is no interference because the Gen C2-1-6-1 and Gen C2-1-6-1-1 lines showed excellent yield numbers (Table 3 ). 
Table 3 - Comparison of the mean values of grain colorimetric parameters ( $L^{*}$ value) of 25 common bean genotypes grown in the 2009 and 2010 rainy sowing seasons, 2010 and 2011 dry sowing seasons and the 2010 and 2011 winter sowing seasons in environments in the state of São Paulo.

\begin{tabular}{|c|c|c|c|c|}
\hline \multirow[t]{2}{*}{ Genotypes } & Rainy & Dry & Ninter & $\begin{array}{c}\text { Joint } \\
\text { analysis }\end{array}$ \\
\hline & $L^{*}$ & $L^{*}$ & $L^{*}$ & $\mathrm{~L}^{*}$ \\
\hline Gen C2-1-6-1 (IAC Carioca) & $53.06 \mathrm{a}^{1}$ & $56.76 a$ & $54.14 \mathrm{a}$ & $54.65 a$ \\
\hline Gen C2-1-6-1-1 (IAC Carioca) & $52.71 \mathrm{a}$ & $56.71 \mathrm{a}$ & $54.28 \mathrm{a}$ & $54.56 a$ \\
\hline Gen C2-3 & $53.61 \mathrm{a}$ & 56.36 a & $52.49 \mathrm{~b}$ & $54.15 a$ \\
\hline en C4-5-4-1-2 (IAC Carioca) & $50.01 \mathrm{~b}$ & 56.57 a & $54.46 \mathrm{a}$ & $53.67 a$ \\
\hline IAC Imperador (IAC Carioca) & $52.41 \mathrm{a}$ & $53.22 \mathrm{c}$ & $52.98 b$ & $52.87 b$ \\
\hline Gen P5-4-4-1 (IAC Carioca) & $52.48 \mathrm{a}$ & $54.41 b$ & $50.95 c$ & $52.61 b$ \\
\hline (C Carioca) & $50.47 b$ & $51.93 \mathrm{c}$ & $49.98 d$ & $50.79 c$ \\
\hline Gen C4-8-1-1(IAC Carioca) & $51.00 \mathrm{~b}$ & $54.32 \mathrm{~b}$ & $52.14 \mathrm{~b}$ & $52.48 b$ \\
\hline arioca) & $50.19 b$ & $52.21 \mathrm{c}$ & $48.71 \mathrm{~d}$ & $50.36 c$ \\
\hline BRS Estil & $50.08 b$ & $53.71 b$ & $51.21 \mathrm{c}$ & $51.66 \mathrm{~b}$ \\
\hline PR Eld & $51.11 \mathrm{~b}$ & $54.57 \mathrm{~b}$ & $50.76 \mathrm{c}$ & $52.14 b$ \\
\hline LP 0403 & $52.99 a$ & $53.10 b$ & $53.08 b$ & $53.06 b$ \\
\hline LP 0 & $51.62 \mathrm{a}$ & $53.28 \mathrm{c}$ & $51.47 c$ & $52.12 b$ \\
\hline $\mathrm{CHCS}$ & & $7 \mathrm{c}$ & & \\
\hline MAll-22 & $9 \mathrm{~b}$ & $52.91 \mathrm{c}$ & $50.07 d$ & $50.52 c$ \\
\hline RP-2 (l & $50.68 b$ & $54.46 b$ & $50.96 \mathrm{c}$ & $52.03 b$ \\
\hline${ }^{2} \mathrm{IAC}$ Alvorada & $50.22 b$ & 55.77 a & $51.80 \mathrm{c}$ & $52.59 \mathrm{~b}$ \\
\hline ²BRS Pérola & $48.33 b$ & $52.72 \mathrm{c}$ & $50.19 \mathrm{~d}$ & $50.41 \mathrm{c}$ \\
\hline${ }^{1}$ Mean Value & $51.06 \mathrm{~B}$ & $54.39 \mathrm{~A}$ & $51.72 \mathrm{~B}$ & 52.39 \\
\hline CV (\%) & 7.83 & 4.03 & 4.40 & 6.32 \\
\hline Gen Pr11-3 & $24.08 a^{1}$ & $24.13 a$ & $23.87 a$ & $24.02 \mathrm{a}$ \\
\hline Gen Pr14-2-3-2 ( & $23.60 \mathrm{a}$ & $23.25 b$ & $23.83 a$ & $23.56 b$ \\
\hline BRS Esplendor (Embrapa Preto) & $24.66 a$ & $24.26 a$ & $24.10 \mathrm{a}$ & $24.34 \mathrm{a}$ \\
\hline BRS Esteio (Embrapa Preto) & $23.93 \mathrm{a}$ & $24.31 \mathrm{a}$ & $24.09 \mathrm{a}$ & $24.10 a$ \\
\hline CHP98-59 (Epagri Preto) & $23.65 a$ & $23.69 b$ & $24.51 \mathrm{a}$ & $23.94 a$ \\
\hline${ }^{2} \mathrm{IAC}$ Diplomata (IAC Preto) & $23.94 \mathrm{a}$ & $23.64 b$ & $24.07 \mathrm{a}$ & $23.88 a$ \\
\hline 2IAC Una (IAC Preto) & $23.14 \mathrm{a}$ & $23.40 \mathrm{~b}$ & $24.57 \mathrm{a}$ & $23.70 \mathrm{~b}$ \\
\hline${ }^{1}$ Mean Value & $23.86 \mathrm{~B}$ & $23.81 \mathrm{~B}$ & $24.15 \mathrm{~A}$ & 23.93 \\
\hline $\mathrm{CV}(\%)$ & 6.16 & 2.97 & 3.65 & 4.58 \\
\hline
\end{tabular}

$\mathrm{L}^{*}$ (unit of measure): Luminosity; ${ }^{1}$ Mean values followed by the same small letter in the column do not differ (Scott-Knott test, $p<0.05$ ); ${ }^{2}$ Values in bold print correspond to the standard cultivars.

\section{Conclusions}

For the combination of the crop seasons from 2009 to 2011, no genotypes superior to the controls for grain yield were observed for the black and carioca seed coat groups. It was possible to the IAC Imperador and BRS Esplendor genotypes as being resistant to anthracnose, Fusarium wilt and Curtobacterium wilt. The dry crop season had lighter-colored grains, while the shortest cooking times were obtained in the rainy crop season. The genotypes with a lightercolored seed coat, like Gen C2-1-6-1, Gen C2-1-6-1-1, Gen C2-3-1-1-2, Gen C4-5-4-1-2 and the IAC Alvorada cultivar, were more susceptible to anthracnose and to Fusarium wilt.

\section{Acknowledgments}

To the Brazilian National Council for Scientific and Technological Development (CNPq) and to the São Paulo State Foundation for Research Support (FAPESP) for financing the studies.

\section{References}

Alves-Santos, F.M.; Ramos, B.; Garcia-Sanchez, M.A.; Eslava, A.P.; Diaz-Minguez, J.M.A. 2002a. DNA-based procedure for in planta detection of Fusarium oxysporum f. sp. phaseoli. Phytopathology 92: 237-244.

Alves-Santos, F.M.; Cordeiro-Rodrigues, L.; Sayagués, J.M.; Martin-Dominguez, R.; Garcia-Benavides, P.; Díaz-Mínguez, J.M.; Eslava, A.P. 2002b. Pathogenicity and race characterization of Fusarium oxysporum f. sp. phaseoli isolates from Spain and Greece. Plant Pathology 51: 605-611.

Beninger, C.W.; Gu, L.; Prior, R.L.; Junk, D.C.; Vandenberg, A.; Bett, K.E. 2005. Changes in polyphenols of the seed coat during the after-darkening process in pinto beans (Phaseolus vulgaris L.). Journal of Agricultural and Food Chemistry 53: 7777-7782.

Carbonell, S.A.M.; Ito, M.F.; Pompeu, A.S.; Francisco, F.G.; Ravagnani, S.; Almeida, A.L.L. 1999. Physiological races of Colletotrichum lindemuthianum and reaction of common bean lines and cultivars in São Paulo state. Fitopatologia Brasileira 24: 60-65 (in Portuguese, with abstract in English).

Carbonell, S.A.M.; Azevedo Filho, J.A.; Dias, L.A.S.; Garcia, A.A.F.; Morais, L.K. 2004. Common bean cultivars and lines interactions with environments. Scientia Agricola 61: 169177 .

Chiorato, A.F.; Carbonell, S.A.M.; Vencovsky, R.; Fonseca Junior, N.S.; Pinheiro, J.B. 2010. Genetic gain in the breeding program of common beans at IAC from 1989 to 2007. Crop Breeding and Applied Biotechnology 10: 329-336.

Cruz, C.D. 2013. Genes: a software package for analysis in experimental statistics and quantitative genetics. Acta Scientiarum 35: 271-276.

Dalla Corte, A.; Moda-Cirino, V.; Scholz, M.B.S.; Destro, D. 2003. Environment effect on grain quality in early common bean cultivars and lines. Crop Breeding and Applied Biotechnology 3: 193-202.

Hsieh, T.F.; Huang, H.C.; Conner, R.L. 2004. Bacterial wilt of bean: current status and prospects. p. 181-206. In: Pandalai, S.G., ed. Recent research developments in plant science. Research Signpost, Kerala, India.

Islam, F.M.A.; Rengifo, J.; Redden, R.J.; Basford, K.E.; Beebe, S.E. 2003. Association between seed coat Polyphenolics (Tannins) and disease resistance in common bean. Plant Foods for Human Nutrition 58: 285-297.

McCouch, S.R. 2005. Diversifying selection in plant breeding. PLoS Biology 2: 1507-1512.

Peña-Valdivia, C.B.; Garcia-Nava, J.R.; Aguirre, J.R.R.; YbarraMoncada, M.C.; López, M.H. 2011. Variation in physical and chemical characteristics of common bean (Phaseolus vulgaris L.) grain along a domestication gradient. Chemistry \& Biodiversity 8: 2211-2225. 
Perina, E.F.; Carvalho, C.R.L.; Chiorato, A.F.; Lopes, R.L.T.; Gonçalves, J.G.R.; Carbonell, S.A.M. 2014. Technological quality of common bean grains obtained in different growing seasons. Bragantia 73: 14-22.

Perseguini, J.M.K.C.; Chiorato, A.F.; Zucchi, M.I.; Colombo, C.A.; Carbonel, S.A.M.; Mondego, J.M.C.; Gazaffi, R.; Garcia, A.A.F.; Campo, T.; Souza, A.P.; Rubiano, L.B. 2011. Genetic diversity in cultivated carioca common beans based on molecular marker analysis. Genetics and Molecular Biology 34: 88-102.

Proctor, J.R.; Watts, B.M. 1987. Development of a modified Mattson bean cooker procedure based on sensory panel cook ability evaluation. Canadian Institute of Food Science and Technology 20: 9-14.

Ribeiro, N.D.; Storck, L.; Poersch, N.L. 2008. Classify the common bean commercials lots by the clarity of the grain tegument. Ciência Rural 38: 2042-2045 (in Portuguese, with abstract in English).
Shimelis, E.A.; Rakshit, S.K. 2005. Proximate composition and physico-chemical properties of improved dry bean (Phaseolus vulgaris L.) varieties grown in Ethiopia. LWT - Food Science and Technology 38: 331-338.

Souza, V.L.; Maringoni, A.C.; Carbonell, S.A.M.; Ito, M.F. 2006. Genetic resistance to Curtobacterium flaccumfaciens pv. flaccumfaciens in bean genotypes. Summa Phytopathologica 32: 39-344 (in Portuguese, with abstract in English).

Torga, P.P.; Melo, P.G.S.; Pereira, H.S.; Faria, L.C.; Del Peloso, M.J.; Melo, L.C. 2013 Interaction of common beans cultivars of the black group with years, locations and sowing seasons. Euphytica 189: 239-248.

Wang, N.; Daun, J.K.; Malcolmson, L.J. 2003. Relationship between physicochemical and cooking properties, and effects of cooking on antinutrients, of yellow field peas (Pisum sativum). Journal of the Science of Food and Agriculture 83: 1228-1237. 